\title{
PENGARUH PEMBERIAN JUS TOMAT BERKULIT DAN TANPA KULIT (LYCOPERSICUM COMMUNE) TERHADAP PENURUNAN KADAR KOLESTEROL LDL PADA LANJUT USIA HIPERKOLESTEROLEMI
}

\author{
Dewi Masithoh Nur, Aryu Chandra ${ }^{*}$ \\ Program Studi Ilmu Gizi Fakultas Kedokteran Universitas Diponegoro \\ J1.Dr.Sutomo No.18, Semarang, Telp (024) 8453708, Email : gizifk@ undip.ac.id
}

\begin{abstract}
Backgound : Hypercholesterolemia is a risk factor of atherosclerosis that impact of cardiovascular diseases in the elderly. The role of lycopene for controlling the cholesterol metabolism and leading to decreased Low-Density Lipoprotein cholesterol.

Objective : The aim of this study was to analyze the effect of tomato juice (Lycopersicum commune) whole and peeled to decreased LDL cholesterol levels in the elderly hipercholesterolemi.

Method : This study was a quasi experimental with pre - post goup design. Subjects were hypercholesterolemia elderly with LDL cholesterol levels $100-159 \mathrm{mg} / \mathrm{dl}$. Subjects devided in 2 goup, i.e first treatment goup (whole tomato juice) and second treatment goup (peeled tomato juice) use doses $150 \mathrm{~g}$ raw tomato was blanching for at least 1 minute with added $50 \mathrm{ml}$ water and $2 \mathrm{~g}$ of sugar for 14 days. Mann-whitney test were used to analyze diference treatment between 2 goups.

Conclusion : There was decreasing LDL cholesterol levels before and after treatment in each goup, but no significant difference between 2 goups.

Key words : Whole tomato juice; peeled tomato juice; LDL cholesterol; elderly
\end{abstract}

\begin{abstract}
ABSTRAK
Latar Belakang : Hiperkolesterolemi menyebabkan terjadinya atherosclerosis yang dapat meningkatkan risiko terjadinya penyakit kardiovaskuler pada lanjut usia. Likopen berperan dalam mengatur metabolisme kolesterol dan dapat menurunkan kadar kolesterol terutama Low-Density Lypoprotein (LDL).

Tujuan : Menganalisis pengaruh pemberian jus tomat (Licopersicum commune) dengan kulit dan tanpa kulit terhadap penurunan kadar kolesterol LDL pada lansia hiperkolesterolemi.

Metode : Penelitian ini merupakan penelitian quasi experimental dengan rancangan pre-post gup design. Subyek pada penelitian ini adalah lanjut usia hiperkolesterolemi yang memiliki kadar kolesterol LDL 100 - 159 mg/dl. Subyek dibagi menjadi 2 kelompok yaitu kelompok perlakuan I (jus tomat dengan kulit) dan kelompok perlakuan II (jus tomat tanpa kulit) dengan dosis $150 \mathrm{~g}$ tomat yang di blanch selama 1 menit dengan penambahan air $50 \mathrm{ml}$ dan gula 2 gam selama 14 hari. Data diuji dengan Mann-whitney untuk mencari perbedaan pengaruh antara kelompok perlakuan I dan II.

Hasil : Terdapat penurunan kadar kolesterol LDL sebelum dan sesudah perlakuan pada masing-masing kelompok, tetapi antara kelompok I dan II tidak terdapat perbedaan penurunan kolesterol LDL yang bermakna.
\end{abstract}

Kata kunci : Jus tomat dengan kulit; jus tomat tanpa kulit; kolesterol LDL; lanjut usia

\section{PENDAHULUAN}

Hiperkolesterolemi didefinisikan sebagai meningkatnya serum kolesterol diatas batas normal. ${ }^{1}$ Faktor risikoterjadinya hiperkolesterolemi yaitu obesitas, asupan makanan (tinggi kolesterol, lemak jenuh dan lemak trans), diabetes melitus, hipertiroidisme, dan sindrom nefrotik. Kadar lipid dalam darah yang berlebihmeningkatkan risiko terjadinya aterosklerosis dan berdampak pada penyakitkardiovaskuler. Berdasarkan penelitian profil lipid penduduk lanjut usia (lansia) di Jakarta tahun 2005 terdapat $19,8 \%$ memiliki kadar kolesterol low-density lipoprotein (LDL) tinggi (>160 mg/dl). ${ }^{2}$ Lansia membutuhkan bantuan dalam merawat diri dengan harapan agar lansia dapat tetap sehat, tetap aktif dan mandiri.

Lansia termasuk kelompok rawan gizi dimana sudah terjadi perubahan fisiologis karena proses penuaan. Pemilihan makanan bergizi pada lansia diperlukan untuk kesehatan dan mencegah penyakit atau komplikasi dari penyakit yang sudah diderita lansia. Zat gizi yang dipercaya dapat menunjang kesehatan dan mencegah penyakit jantung diantaranya karotenoid, polifenol (flavonoid dan non-flavonoid), asam lemak omega 3, dan allinin (pada bawang putih). Salah satu karotenoid yang terdapat dalam makanan adalah likopen. Sumber bahan makanan yang mengandung likopen salah satunya adalah tomat. ${ }^{3}$

${ }^{*}$ Penulis Penanggungjawab 
Tomat memiliki komponen bioaktif dan zat gizi seperti potasium, asam folat, vitamin A, C, dan E. Selain itu, tomat mengandung campuran dari karotenoid antara lain carrotenoid lycopene (LYC), $\gamma$-carotene, phytoene (PE), neurosprene, phytofluene $(P F), \beta$-carotene, dan lutein. Tomat pada tahap matang ditandai dengan perubahan warna menjadi merah karena mengandung karotenoid, yang juga mengandung zat gizi dan bioaktif lain seperti tocopherols, asam folat, phenolics, glycoalkaloids, flavonoids. ${ }^{4}$

Tomat merupakan bahan pangan yang murah, mudah didapat, mudah diolah, dan lunak, sehingga lansia mudah mengonsumsinya. Buah tomat sebagian besar pemanfaatannya hanya sebatas sebagai lalapan, bahan tambahan dalam masakandan sebagai minuman yang diolah menjadi jus. Likopen dalam tomat memiliki peranan dalam mencegah terjadinya penyakit kardiovaskuler. Likopen berperan dalam mengatur metabolisme kolesterol dengan menghambat kerja enzim HMG-KoA reduktase (enzim yang berperan dalam sintesis kolesterol di hepar) dan meningkatkan degradasi kolesterol LDL. ${ }^{5}$

Beberapa olahan tomat tanpa kulit antara lain sirup, puree, saos dan tomat kalengan.Rerata kandungan likopen dalam 100gtomat utuh 10,7 mg, sedangkan rerata kandungan likopen dalam 100 gtomat tanpa kulit adalah $2,1 \mathrm{mg}$. Tomat yang dikupas mengalami penurunan kadar likopen sampai 80\%. ${ }^{6}$ Likopen dalam tomat yang mengalami proses pemasakan berubah bentuk dari all-trans lycopene menjadi cis-lycopene isomers yang lebih larut dalam misel asam basa sehingga lebih mudah dicerna. ${ }^{7}$

\section{METODE}

Penelitian ini adalah quasi experimental dengan rancangan desain faktorialyang menggunakan manusia sebagai subyek penelitian. Variabel terikat dalam penelitian ini adalah kadar kolesterol LDL lansia hiperkolesterolemi, sedangkan variabel bebas dalam penelitian adalah pemberian jus tomat.

Subyek penelitian adalah lansia yang dibina di panti wreda Kota Semarang diambil dengan menggunakanmetode consecutive samplingyang memenuhi kriteria antara lain berusia 60-75 tahun, memiliki kadar LDL antara 100-159 mg/dl, tidak mengonsumsi obat atausuplemen anti hiperkolesterolemi dan tidak dalam kondisi sakit atau dalam perawatan dokter terkait penyakit kronis. Proses pengambilan subyekdilakukan dengan menawarkan kesediaan menjadi subyek penelitian pada populasi saat dilakukan sosialisasi penelitian. Kriteria eksklusi pada penelitan yaitu subyek tidak kooperatif, mengundurkan diri saat penelitian berlangsung, dan meninggal dunia saat penelitian berlangsung. Subyek yang bersedia diminta untuk menandatangani informed consent. Selanjutnya dilakukan proses wawancara sertapengukuran kadar kolesterol LDL untuk mengetahui apakah kadar kolesterol LDL subyek memenuhi kriteria inklusi.

Subyek yang memenuhi kriteria dinyatakan sebagai subyekpenelitian kemudian dibagi menjadi dua kelompok yaitu kelompok perlakuan I (mendapat jus tomat berkulit) dan kelompok perlakuan II (mendapat jus tomat tanpa kulit) selama 14 hari. Setelah subyek diberi jus tomat sesuai perlakuan kemudian dilakukan pengukuran kadar kolesterol LDL.

Subyek pada awal penelitian terdapat 30 orang. Namun, dalam akhir penelitian hanya 27 subyek karena meninggal dunia dan tidak kooperatif. Variabel bebas dalam penelitian ini yaitu pemberian jus tomat berkulit $150 \mathrm{~g}$ tomat merah yang diblanch dengan penambahan air 50 $\mathrm{ml}$ dan gula 2 gperhari selama 14 hari dan pemberian jus tomat tanpa kulit dengan dosis danjangkawaktuyang sama. Variabel terikat pada penelitian ini yaitu kadar kolesterol LDL pada kedua kelompok perlakuan

Data yang terkumpul berupa data umum dan kondisi kesehatan berdasarkan catatan di panti dan wawancara dengan subyek, serta kadar kolesterol LDL. Pengukuran kadar kolesterol LDL dilaksanakan dilaboratorium swasta dengan metode LDL Cholesterol Direct Assav.Data yang diperoleh kemudian diolah dengan progam komputer SPSS 17 dan diuji normalitas menggunakan uji Saphiro Wilk. Hasil pengujian data diuji dengan Mann-whitneyuntuk mencari perbedaan pengaruh antara kelompok perlakuan I dan II. Uji lanjutan yaitu dengan uji Wilcoxon, yang bertujuan untuk melihat perbedaan kolesterol LDL sebelum dan sesudah perlakuan pada kelompok I, sedangkan untuk melihat perbedaan kolesterol LDL sebelum dan sesudah perlakuan pada kelompok II menggunakan dependent t-test. 
HASIL PENELITIAN

Karakteristik Subyek Sebelum Perlakuan

Pemilihan subyek untuk menjadi subyek penelitian dengan skrining terhadap kelompok lanjut usia (lansia) di tiga tempat rehabilitasi atau panti jompo Kota Semarang. Panti wredaA diperoleh 6 subyek, daripantiwreda B diperoleh 8 subyekdandaripantiwreda $\mathrm{C}$ diperoleh 15 subyek. Gambaran usia dan jenis kelamin subyek disajikan dalam tabel 1.

Tabel 1. Karakteristik UsiadanJenisKelamin Subyek

\begin{tabular}{lcccc}
\hline \multirow{2}{*}{ JenisPengukuran } & \multicolumn{2}{c}{ Kelompok I } & \multicolumn{2}{c}{ Kelompok II } \\
\cline { 2 - 5 } & $\mathbf{N}$ & $\mathbf{\%}$ & $\mathbf{N}$ & \% \\
\hline Usia & & & 5 & 35,71 \\
\hline 60-65 tahun & 5 & 38,46 & 5 & 35,71 \\
66-70 tahun & 3 & 23,08 & & 28,58 \\
71-75 tahun & 5 & 38,46 & 4 & 50,00 \\
\hline JenisKelamin & & & & 50,00 \\
\hline Laki-laki & 7 & 53,85 & 7 & \\
Perempuan & 6 & 46,15 & 7 & \\
\hline
\end{tabular}

Tabel 1 menunjukkanpadakelompok I dan sama. Gambaran berat badan dan kolesterol LDL II jumlah subyek laki-laki dan perempuan hampir subyek sebelum perlakuan disajikan dalam tabel 2.

Tabel 2. Karakteristik BeratBadandanKolesterol LDL Subyek

\begin{tabular}{lccccccc}
\hline \multirow{2}{*}{ Jenis Pengukuran } & \multicolumn{5}{c}{ Kelompok I $(\mathrm{n}=13)$} & \multicolumn{3}{c}{ Kelompok II $(\mathrm{n}=14)$} & \multirow{2}{*}{$\mathrm{P}$} \\
\cline { 2 - 7 } & Min & Max & Mean \pm SD & Min & Max & Mean \pm SD & \\
\hline Berat Badan & 42,00 & 63,00 & $\begin{array}{c}53,08 \pm \\
6,89\end{array}$ & 48,00 & 65,00 & $\begin{array}{c}56,93 \pm \\
4,21\end{array}$ & $0,141^{\text {a }}$ \\
\hline $\begin{array}{l}\text { Kolesterol LDL } \\
\text { sebelumperlakuan }\end{array}$ & 100,8 & 151,2 & $\begin{array}{c}123,26 \pm \\
12,90\end{array}$ & 101,3 & 150,2 & $\begin{array}{c}126,87 \pm \\
18,67\end{array}$ & $0,562^{\mathrm{b}}$ \\
\hline
\end{tabular}

${ }^{\mathrm{a}}$ Mann-Whitney Test

${ }^{\mathrm{b}}$ Independent t-test

Tabel 2 menunjukkankarakteristik berat badan dan kadar kolesterol LDL tidak terdapat perbedaan sebelum perlakuanantara kedua kelompok $(\mathrm{p}>0,05)$.

Pengaruh pemberian jus tomat berkulit dan tanpa kulit terhadap penurunan kadar kolesterol LDL pada lanjut usia hiperkolesterolemi.

Perbedaan kadar kolesterol LDL subyek sebelum dan setelah perlakuan disajikan pada tabel 3.

Tabel 3. Kadar Kolesterol LDL Sebelum dan Sesudah Perlakuan

\begin{tabular}{|c|c|c|c|c|}
\hline \multirow{2}{*}{\multicolumn{2}{|c|}{ Jenis pengukuran }} & Kelompok $1(n=13)$ & Kelompok $2(n=14)$ & \multirow{2}{*}{$\mathrm{P}$} \\
\hline & & Mean + SD & Mean + SD & \\
\hline $\begin{array}{ll}\text { Kolesterol } & \text { LDL } \\
\text { perlakuan }(\mathrm{mg} / \mathrm{dl}) & \end{array}$ & sebelum & $123,26 \pm 12,90$ & $126,87 \pm 18,67$ & \multirow{4}{*}{$0.905^{\mathrm{c}}$} \\
\hline $\begin{array}{l}\text { Kolesterol LDL } \\
\text { perlakuan }(\mathrm{mg} / \mathrm{dl})\end{array}$ & sesudah & $104,72 \pm 15,66$ & $108,12 \pm 13,82$ & \\
\hline$\Delta$ kolesterol LDL & & $-18,54 \pm 11,91$ & $-18,75 \pm 11,97$ & \\
\hline $\mathrm{P}$ & & $0.002^{\mathrm{a}}$ & $0.000^{\mathrm{b}}$ & \\
\hline
\end{tabular}

${ }^{\mathrm{a}}$ uji Wilcoxon, ${ }^{\mathrm{b}}$ dependent t-test, ${ }^{\mathrm{c}}$ uji Mann-whitney

Pada tabel 3 dapat dilihat bahwa terdapat penurunan kadar kolesterol LDL sebelum dan sesudah perlakuan pada kedua kelompok, tetapi antara kelompok I dan II tidak terdapat perbedaan yang bermakna.

\section{PEMBAHASAN}

Pemberian jus tomat berkulit dan jus tomat tanpa kulit pada penelitian ini masing-masing 150 $\mathrm{g}$ tomat dengan penambahan air $50 \mathrm{cc}$ dan gula $2 \mathrm{~g}$ selama 14 hari berpengaruh terhadap kadar 
kolesterol LDL secara bermakna. Hasil uji statistik menunjukkan ada perbedaan bermakna kadar kolesterol LDL sebelum dan sesudah perlakuan pada kedua kelompok $(\mathrm{p}<0,05)$. Kelompok I terdapat penurunan kadar kolesterol LDL dengan rerata sebesar 18,54 $\mathrm{mg} / \mathrm{dl}$, sedangkan pada kelompok II terdapat penurunan kadar kolesterol LDL dengan rerata $18,75 \mathrm{mg} / \mathrm{dl}$.

Zat gizi yang dipercaya dapat menurunkan kadar kolesterol LDL diantaranya karotenoid, polifenol (flavonoid dan non-flavonoid), asam lemak omega 3, dan allinin (pada bawang putih). Salah satu karotenoid yang terdapat dalam makanan adalah likopen. ${ }^{3}$ Likopen adalah salah satu karotenoid larut lemak yang disintesis oleh beberapa mikroorganisme dan tanaman, tapi tidak dapat disintesis oleh hewan dan manusia. Likopen tomat yang diolah sudah mengalami perubahan bentuk dari alltrans isomers menjadi cis-lycopene isomer sehingga mudah diserap. ${ }^{8}$

Likopen diserap secara difusi pasif oleh membran brush border di sel mukosa usus halus yang dibantu oleh garam empedu. Likopen keluar melalui sistem limfe mesentrik dalam bentuk kilomikron yang kemudian masuk dalam darah untuk masuk ke jaringan seperti kelenjar adrenal, ginjal, jaringan adiposa, limpa paru-paru dan organ-organ reproduksi. ${ }^{9}$ Likopen menurunkan kadar kolesterol dengan cara menekan sintesis kolesterol sehingga mengurangi kadar kolesterol sirkulasi pada hewan percobaan, namun suplementasi likopen pada hewan percobaan tidak dapat menghambat aktivitas 3-hydroxy-3methyl glutaryl Coenzyme A (HMG-KoA) reduktase (enzim yang berperan dalam sintesis kolesterol di hepar). Likopen dapat menekan sintesis kolesterol seluler kira-kira $40 \%$ dengan menghambat enzim HMG-KoA pada penelitian dengan subyek manusia. ${ }^{10,11}$

Kadar kolesterol dalam tubuh dipengaruhi oleh asupan dan biosintesis kolesterol. Kolesterol dalam tubuh yang meningkat menyebabkan aktivitas enzim HMG-KoA reduktase menurun. HMG-KoA reduktase berperan untuk membantu proses pembentukan mevalonat. Mevalonat merupakan prekursor pembentukan kolesterol dan produk akhir lainnya seperti dolichol, ubiquinon dan hem. Aktivitas enzim HMG-KoA yang terhambat akan meningkatkan reseptor LDL di permukaan sel hepar sehingga meningkatkan uptake lipoprotein untuk memenuhi kebutuhan sel berupa kolesterol. ${ }^{12,13}$

Hasil penelitian ini sesuai hasil penelitian di Mesir mengenai efek likopen tomat terhadap kadar kolesterol in vivo. Penelitian tersebut membandingkan efek dosis pemberian tomat untuk menurunkan kolesterol LDL antara 7 kelompok. Kelompok 1 adalah kelompok kontrol, kelompok 2 - 5 mendapat likopen tomat masing-masing mengandung 100, 200, 400 dan 800 ppm, sedangkan kelompok 6 mendapat butylated hydroxytoluene $200 \mathrm{ppm}$ dan kelompok 7 mandapat grade lycopene $200 \mathrm{ppm}$ selama 10 minggu. Hasil penelitian tersebut memberikan informasi bahwa likopen pada tomat dapat mencegah meningkatnya kolesterol total dan kolesterol LDL pada tikus yang diberi pakan tinggi kolesterol sehingga kadar kolesterol LDL masingmasing kelompok menurun, tetapi antar kelompok tidak berbeda secara bermakna. ${ }^{14}$

Penelitian ini sudah dilakukan blanching pada tomat untuk meningkatkan kadar likopen, tetapi tidak dilakukan uji kandungan likopen setelah blanching. Kadar likopen dalam tomat yang dimasak lebih tinggi daripada tomat mentah. Tomat yang diolah atau dimasak dengan komponen lain dalam makanan seperti lemak dan serat dapat meningkatkan bioavailibilitas dan absorbsi. $^{7}$ Penelitian di India memberikan informasi bahwa pada bagian kulit dan daging tomat mengandung likopen yang berbeda. Kandungan likopen hasil dari tomat utuh 83,9 $\mu \mathrm{g} / \mathrm{g}$, daging tomat $47,6 \mu \mathrm{g} / \mathrm{g}$ dan pada biji tomat tidak mengandung likopen. Hasil penelitian ini menunjukkan bahwa kulit tomat memiliki konsentrasi karotenoid total tertinggi. Karotenoid total diperkirakan mengandung likopen sebanyak $60-64 \% .{ }^{15}$ Proses pemanasan tomat pada suhu $70^{\circ}$ C selama 30 menit meningkatkan likopen sebanyak 2,4 kali daripada tomat mentah. ${ }^{16}$

Kandungan di dalam tomat selain likopen yang dapat menurunkan LDL adalah campuran dari karotenoid yang terdiri atas $\gamma$-carotene, phytoene (PE), neurosprene, phytofluene (PF), $\beta$ carotene, dan lutein. Beberapa penelitian memberikan informasi bahwa karotenoidkarotenoid berperan dalam absorbsi dan distribusi lipoprotein diantaranya very low-density lipoprotein (VLDL), low-density lipoprotein (LDL), dan high-density lipoprotein (LDL). Likopen berhubungan dengan absorbsi dan distribusi kolesterol LDL, sedangkan PE dan PF berhubungan dengan absorbsi dan distribusi kolesterol VLDL dan HDL. Kandungan PE dan PF dalam tomat mentah adalah $0,82 \mathrm{mg}$ dan $1,86 \mathrm{mg}$ tiap $100 \mathrm{~g}$. PE dan PF merupakan prekursor dari likopen. ${ }^{4}$ 


\section{SIMPULAN}

Terdapat penurunan kadar kolesterol LDL yang bermakna sebelum dan setelah pemberian jus tomat berkulit maupun jus tomat tanpa kulit, namun tidak didapatkan perbedaan penurunan kadar kolesterol LDL yang bermakna pada kedua kelompok.

\section{SARAN}

Jus tomat dapat digunakan sebagai penurun kolesterol LDL pada penderita hiperkolesterolemi.

\section{DAFTAR PUSTAKA}

1. Stapleton PA, Goodwill AG, James ME, Brock RW, Frisbee JC. Hypercholesterolemia and microvascular dysfunction: interventional strategies. Journal of Inflamation 2010;7:54

2. Khairani R, Sumiera M. Profil lipid pada penduduk lanjut usia di Jakarta. Universa Medicina 2005; 24(4)

3. Yang Y, Chan SW, Hu M, Walden R, Tomlinson B. Effects of Some Common Food Constituens on Cardiovaskular Disease. ISRN Cardiology, 2011

4. Engelmann NJ, Clinton SK, Erdman-Jr JW. Nutritional Aspect of Phytoene and Phytofluene, Carotenoid Precussors to Lycopene. Adv. Nutr 2011;2:51-61

5. Iswari RS. Perbaikan Fraksi Lipid Serum Tikus Putih Hiperkolesterolemi Setelah Pemberian Jus dari Berbagai Olahan Tomat. [skripsi]. Univ. Negeri Semarang; 2009

6. Vinha AF, Alves RC, Barreira SVP, Castro A, Costa ASG, Oliveira MBPP. Effect of peel and seed removal on the nutritional value and antioxidant activity of tomato (Lycopersicon esculentum L.) fruits. LWT-Food Science and Technology 2013;55:197-202

7. Ahuja KDK, Pittaway JL, Ball MJ. Effect of olive oil and tomato lycopene combination on serum lycopene, lipid profile, and lipid oxidation 2006. J.Nutr;22:259-265

8. Rao AV, Rao LG. Carotenoids and human health. Pharmacologycal Research 2007;55:207-216

9. Sulistyowati Y. Pengaruh pemberian likopen terhadap status antioksidan (vitamin C, vitamin E dan Glthathion Peroksidase) tikus hiperkolesterolemik. [tesis]. Univ.Diponegoro; 2006

10. Lorenz M, Fechner M, Kalkowski J, Fröhlich K, Trautmann A, Böhm V, et al. Effect of Lycopene on the Initial State of Atherosclerosis in New Zealand White (NZW) Rabbits. PloS ONE 2012; $7(1)$

11. Silaste ML, Alfthan G, Aro A, Kesäniemi YA, Hörkkö S. Tomato Juice decreases LDL cholesterol levels and increases LDL resistance to oxidation. British Journal of Nutrition 2007;98:1251-1258

12. Gropper SS, Smith JL, Groff JL. Advanced Nutrition and Human Metabolism. Fifth Edition. Canada: Wadsworth Cengange Learning; 2009.p. 166-167

13. Fuhrman B, Elis A, Aviram M. Hypocholesterolemic Effect of Lycopene and $\beta$ Carotene is Related to Supression of Cholesterol Synthesis and Augmentation of LDL Receptor Activity in Macrophages. BIOCHEMICAL AND BIOPHYSICAL COMMUNICATION 1997;233:658-662

14. Basuny AM, Gaafar AM, Arafat SH. Tomato lycopene is a natural antioxidant and can alleviate hypocholesterolemia. African Journal of Biotechnology 2009;8(9):6627-6633

15. Ranveer RC, Patil SN, Sahoo AK. Effect of different parameters on enzyme-assisted extraction of lycopene from tomato processing waste. Food and Bioproduct Processing 2013;91:370-375

16. Demiray E, Tulek Y, Yilmaz Y. Degradation kinetics of lycopene, $\beta$-carotene and ascorbic acid in tomatoes during hot air drying. Food Science and Technology 2013;50:172-176 